\section{Евтюхин Юрий Алексеевич}

кандидат юридических наук, доцент, доцент кафедры теории и истории государства и права Кемеровского института (филиала) Российского экономического университета им. Г.В. Плеханова

\section{ПРОБЛЕМЫ ТОЛКОВАНИЯ КОНСТИТУЦИОННО-ПРАВОВЫХ АКТОВ}

\section{Аннотация:}

В статье рассматриваются проблемы, возникающие при толковании правовых актов в процессе преподавания конституционного права России. Автор обращает внимание на то, что правильное понимание оценочных и моральных норм вызывает затруднения. У этих норм нет конкретного юридического содержания. Правоприменитель получает возможность действовать по собственному усмотрению. Это создает условия для произвола. Высказаны предложения использовать ограниченное аутентичное толкование, наделить законодательный орган правом разъяснять такие нормы. При толковании конституционноправовых актов выявляются противоречия между буквой закона и духом закона. Норма закона может вступать в противоречие с принципами права. Подобные конфликты отрицательно влияют на формирование правосознания и мировоззрения студентов, могут привести к нарушениям в дальнейшей профессиональной деятельности.

Ключевые слова:

толкование права, оценочные нормы, нормы морали, буква закона, дух закона.

\section{Evtyukhin Yury Alekseevich}

PhD in Law, Associate Professor, Department of Theory and History of State and Law,

Kemerovo Institute (branch) of Plekhanov Russian University of Economics

\section{PROBLEMS OF INTERPRETING CONSTITUTIONAL LAWS AND REGULATIONS}

Summary:

The paper discusses the problems of interpreting laws and regulations while teaching the constitutional law in Russia. The author emphasizes that the proper understanding of evaluation and moral standards remains a challenge. These standards have no specific legal content. A law enforcement official gets an opportunity to act at his own discretion. It causes an abuse. The author proposes using a narrow authentic interpretation of the law, empowering the legislative body to clarify such standards. While interpreting the constitutional laws and regulations, the research identifies the distinctions between the letter of the law and the spirit of the law. The standards of the law may be in conflict with the principles of the law. Such contradictions have a negative impact on the development of the legal awareness and worldview of students and can lead to the breaches in their future professional activities.

Keywords:

interpretation of the law, evaluation standards, moral standards, the letter of the law, the spirit of the law.

Разным аспектам теории толкования правовых норм, правовых актов, права в целом посвящено немало научных исследований. В учебной литературе этой теме также уделено существенное внимание, в каждом учебнике по теории государства и права есть соответствующая глава или параграф. Авторы практически единодушны в том, что успешностью процесса толкования юридических норм обусловлена эффективность правоприменительной деятельности. Так, А.И. Овчинников и С.П. Овчинникова пишут: «От понимания права и юридического мышления, их интерпретационной деятельности зависит эффективность механизма правового регулирования. Прежде чем норма начинает действовать, должна быть решена задача ее конкретизации - самая сложная задача в правоприменительном процессе» [1, с. 106].

Однако поводом для написания данной статьи послужила не связь процессов толкования и применения права, а проблемы, возникающие при толковании правовых актов при преподавании конституционного права России на юридическом фракультете вуза. Одна из них вызвана наличием в конституционно-правовых актах оценочных норм и моральных понятий. Как замечает О.М. Беляева, «чрезмерное включение оценочных понятий в нормативные акты усложняет толкование» [2, с. 84].

Обратимся к ряду примеров. В ст. 13 Федерального закона от 31.05.2002 г. № 62-Ф3 «О гражданстве Российской Федерации» говорится, что иностранные граждане и лица без гражданства могут быть приняты в гражданство Российской Федерации в общем порядке, если «имеют законный источник средств к существованию» [3]. Возникают естественные вопросы. Какой уровень «существования» должны обеспечить имеющиеся у лица средства? Какой размер средств можно считать достаточным для обеспечения существования? Этих вопросов можно было бы избежать, если бы закон связал размер средств к существованию с прожиточным минимумом, установленным в России для разных категорий лиц, сделал его равным прожиточному минимуму или двум, трем его размерам.

В этой же статье закона сказано, что срок проживания на территории Российской Федерации сокращается до одного года при «наличии у лица высоких достижений в области науки, техники и культуры». Законодатель не говорит о том, какие достижения можно считать «высокими». 
Разумеется, если гражданином России желает стать лауреат Нобелевской премии, значимость достижения очевидна. Но как быть, если о приеме в гражданство ходатайствует представитель авангардного искусства? Отношение к нему в обществе весьма неоднозначно. Уместно вспомнить гонения на художников-авангардистов в период советской власти.

Еще одним примером оценочной правовой нормы является статья 6 Федерального конституционного закона от 26.02.1997 г. № 1-ФКЗ «Об Уполномоченном по правам человека в Российской Федерации». В ней сказано, что на эту должность может быть назначено лицо, «имеющее познания в области прав и свобод человека и гражданина, опыт их защиты» [4]. Какое образование должен иметь гражданин, чтобы считаться обладающим требуемыми познаниями, сколько лет и в какой должности ему нужно проработать, чтобы приобрести опыт защиты прав и свобод человека и гражданина? Закон на эти вопросы не отвечает.

Неоднократно на занятиях студенты обращали внимание на то, что В.П. Лукин, работавший в этой должности с 2004 по 2014 г., имеет историческое образование и до назначения уполномоченным занимался дипломатической и политической деятельностью. Первая, по их мнению, связана с защитой прав и свобод лишь косвенно, а опыт политической деятельности вообще бесполезен, так как в ст. 11 названного закона уполномоченному запрещено ею заниматься. Приходится убеждать студентов в том, что знания в сфрере прав и свобод можно приобрести не только на юридическом фракультете, а политическая деятельность вполне может быть сопряжена с их защитой.

Достаточно трудно выявить юридическое содержание нормы, закрепленной в ст. 12 Федерального закона от 26.09.1997 г. № 125-Ф3 «О свободе совести и о религиозных объединенияХ», согласно которой религиозной организации может быть отказано в государственной регистрации, если «создаваемая организация не признана в качестве религиозной» [5]. В законе нет четких критериев, по которым регистрирующий орган может признать или не признать организацию религиозной.

Адаптацию этой нормы к реальным условиям взяло на себя Министерство юстиции РФ, утвердившее приказом № 53 от 18.02.2009 г. Порядок проведения государственной религиоведческой экспертизы. В субъектах Российской Федерации при управлениях Минюста образуются Экспертные советы по проведению государственной религиоведческой экспертизы. В составе совета, сформированного в Кемеровской области, заместителем председателя которого является автор этой статьи, состоят два государственных гражданских служащих, доктор культурологии, доктор философских наук, кандидат философских наук, кандидат исторических наук. Безусловно, каждый выступает специалистом в своем деле. Экспертный совет без труда обнаружит попытку граждан зарегистрировать под видом религиозной организации хозяйствующий субъект, чтобы «оптимизировать» уплату налогов, выявит в уставе организации экстремистские цели, установит, осуществляются ли религиозные обряды, но при решении мировоззренческих, теологических вопросов испытает затруднения. В этих сферах, как известно, абсолютных истин нет. Как гласит латинское выражение - Credo quia absurdum (верую, потому что нелепо).

Очень трудно, если вообще возможно, толковать получившие юридическое закрепление нормы морали. В ст. 2 Федерального закона от 03.12.2012 г. № 229-Ф3 «О порядке формирования Совета Федерации Федерального собрания Российской Федерации» сказано, что кандидатом для наделения полномочиями члена Совета Федерации может быть гражданин России, «обладающий безупречной репутацией» [6]. Мораль довольно изменчива и в значительной мере зависит от исторических условий жизни общества, воспитания, вероисповедания и других обстоятельств. Существует достаточно иллюзорная категория "общепризнанная мораль», которой должны руководствоваться граждане в демократическом цивилизованном государстве. Иллюзорность этого «универсального» понятия обнаруживается достаточно просто: во Франции признаются однополые браки [7], а в России у подавляющего большинства населения гомосексуализм вызывает полное неприятие. Соответственно, российское общество не признает безупречной репутацию у лица с нетрадиционной сексуальной ориентацией.

На занятиях практически всегда студенты спрашивают о том, как оценивать репутацию тех, кто ушел от беременной жены, проявляет супружескую неверность, имеет внебрачных детей? Таким образом, вопросы сводятся к тому, является ли частная жизнь гражданина критерием оценки его репутации.

Облегчить толкование оценочных и моральных норм мог бы сам законодатель, включая в текст правового акта расширенный перечень дефиниций [8, с. 151]. Например, в Федеральном законе от 30.04.1999 г. № 82-Ф3 «О гарантиях прав коренных малочисленных народов Российской Федерации» содержатся развернутые определения терминов «коренные малочисленные народы», «традиционный образ жизни», «исконная среда обитания» [9].

Возможным выходом из затруднений при толковании оценочных и моральных норм могло бы стать аутентичное толкование. В научной литературе высказано немало возражений против наделения законодателя правом толковать принятые им же правовые нормы. Э.Х. Губайдуллина видит в аутентичном толковании «широкий простор для обхода закона и для бесконтрольного произвола в сфрере правотворческой и правоприменительной деятельности» [10, с. 52]. Полагаем, что столь категорично возражать против аутентичного толкования не следует. Во-первых, 
если целью толкования признается выявление воли законодателя, то почему он не имеет возможности помочь в этом процессе? Во-вторых, сфера аутентичного толкования должна касаться исключительно оценочных и моральных норм. В остальных случаях законодатель обязан исправлять неточности фрормулировок путем внесения изменений в правовой акт.

Существенной проблемой толкования конституционно-правовых актов в учебном процессе является обнаруживаемый при этом конфликт буквы закона и духа закона, т. е. содержания текста закона и принципов права. Обратимся к Федеральному закону от 06.10.1999 г. № 184-Ф3 «Об общих принципах организации законодательных (представительных) и исполнительных органов государственной власти субъектов Российской Федерации» [11]. Он предусматривает возможность отзыва избирателями высшего должностного лица субъекта РФ. Казалось бы, нужно приветствовать закрепление этого института прямого народовластия, демократизм буквы закона очевиден. Однако системное толкование данного правового института разрушает позитивную оценку.

В ст. 19 говорится, что в поддержку инициативы отзыва высшего должностного лица субъекта РФ необходимо собрать подписи не менее одной четверти всех избирателей субъекта РФ. Субъект Федерации вправе законодательно повысить это количество. В Кемеровской области не стали корректировать норму, предложенную федеральным законодателем, но и в этом случае для инициирования отзыва губернатора требуется собрать 560 тысяч подписей!

Высшее должностное лицо субъекта Российской Федерации будет считаться отозванным, если за это проголосует не менее половины избирателей, зарегистрированных в субъекте РФ. Как известно, на выборах всех уровней в России результаты голосования связаны с количеством голосов избирателей, принявших участие в голосовании. Обязательная минимальная явка не установлена. Следовательно, получить мандат может кандидат, за которого проголосует значительно меньше половины зарегистрированных избирателей. Таким образом, для отзыва высшего должностного лица субъекта РФ требуется гораздо больше голосов избирателей, чем для его избрания.

Студенты невольно приходят к выводу, что законодатель умышленно усложнил избирателям процедуру отзыва, чтобы увести чиновников от юридической ответственности перед народом. По их мнению, закон лишь имитирует право граждан влиять на губернаторов, хотя дух закона в демократическом государстве предполагает верховенство прав и свобод человека и гражданина. Это вытекает из ст. 2 Конституции России, провозглашающей, что «человек, его права и свободы являются высшей ценностью» [12].

Проблемы, заявленные в статье, не следует рассматривать исключительно как трудности образовательного процесса. Они требуют разрешения, поскольку имеют далеко идущие последствия. В конституционно-правовых актах в большей степени, чем в нормативных актах иных отраслей, закрепляются демократические основы государственного и общественного развития. Их правильное уяснение студентами является одним из условий фрормирования гражданственности, мировоззрения и правосознания молодежи, успешного применения права в будущей профессиональной деятельности.

\section{Ссылки:}

1. Овчинников А.И., Овчинникова С.П. Современная теория толкования права: классические и неклассические подходы // Юристъ-правоведъ. 2011. № 2. С. 106-115.

2. Беляева О.М. Оценочные понятия и категории как средства юридической техники // Законы России: опыт, анализ, практика. 2013, № 8. С. 83-87.

3. О гражданстве Российской Федерации [Электронный ресурс] : федер. закон от 31 мая 2002 г. № 62-Ф3. Доступ из справ.-правовой системы «КонсультантПлюс».

4. Об Уполномоченном по правам человека в Российской Федерации [Электронный ресурс] : федер. конституционный закон от 26 февр. 1997 г. № 1-ФКЗ. Доступ из справ.-правовой системы «КонсультантПлюс».

5. О свободе совести и о религиозных объединениях [Электронный ресурс] : федер. закон от 26 сент. 1997 г. № 125Ф3. Доступ из справ.-правовой системы «КонсультантПлюс».

6. О порядке формирования Совета Федерации Федерального собрания Российской Федерации [Электронный ресурс] : федер. закон от 3 дек. 2012 г. № 229-Ф3. Доступ из справ.-правовой системы «КонсультантПлюс».

7. LOI n 2013-404 du 17 mai 2013 ouvrant le mariage aux couples de personnes de même sexe [Электронный pecypc]. URL: https://www.legifrance.gouv.fr/affichTexte.do;jsessionid=?cidTexte=JORFTEXT000027414540\&dateTexte=\&oldAction=rechJO\&categorieLien=id (дата обращения: 02.01.2018).

8. Кузьмичева Е.В., Луганцева Е.Д. Виды, способы и результаты толкования норм права с оценочными понятиями // Science Time. 2014. № 9. С. 148-152.

9. О гарантиях прав коренных малочисленных народов Российской Федерации [Электронный ресурс] : федер. закон от 30 апр. 1999 г. № 82-Ф3. Доступ из справ.-правовой системы «КонсультантПлюс».

10. Губайдуллина Э.Х. Аутентичное толкование: нужно ли его относить к официальному виду толкования норм права в РФ? // Вектор науки Тольяттинского государственного университета. Сер.: Юридические науки. 2010. № 2. С. 51-52.

11. Об общих принципах организации законодательных (представительных) и исполнительных органов государственной власти субъектов Российской Федерации [Электронный ресурс] : федер. закон от 6 окт. 1999 г. № 184-ФЗ. Доступ из справ.-правовой системы «КонсультантПлюс».

12. Конституция Российской Федерации [Электронный ресурс] : принята всенародным голосованием 12 дек. 1993 г. Доступ из справ.-правовой системы «КонсультантПлюс». 


\section{References:}

Belyaeva, OM 2013, 'Evaluation concepts and categories as a means of legal technique', Zakony Rossii: opyt, analiz, praktika, no. 8, pp. 83-87, (in Russian).

Gubaidullina, EKh 2010, 'Authentic interpretation: should it be attributed to the official form of interpretation of the law in the Russian Federation?', Vektor nauki Tol'yattinskogo gosudarstvennogo universiteta. Ser.: Yuridicheskiye nauki, no. 2, pp. 51-52, (in Russian).

Kuzmicheva, EV \& Lugantseva, ED 2014, 'Types, methods and results of the interpretation of the law with appraisal concepts', Science Time, no. 9, pp. 148-152, (in Russian).

LOI n 2013-404 du 17 mai 2013 ouvrant le mariage aux couples de personnes de même sexe 2018, viewed 02 January 2018, <https://www.legifrance.gouv.fr/affichTexte.do;jsessionid=?cidTexte=JORFTEXT000027414540\&dateTexte=\&oldAction=rechJO\&categorieLien=id>, (in French).

Ovchinnikov, Al \& Ovchinnikova, SP 2011, 'Modern theory of the interpretation of law: classical and non-classical approaches', Yurist'-pravoved', no. 2, pp. 106-115, (in Russian). 